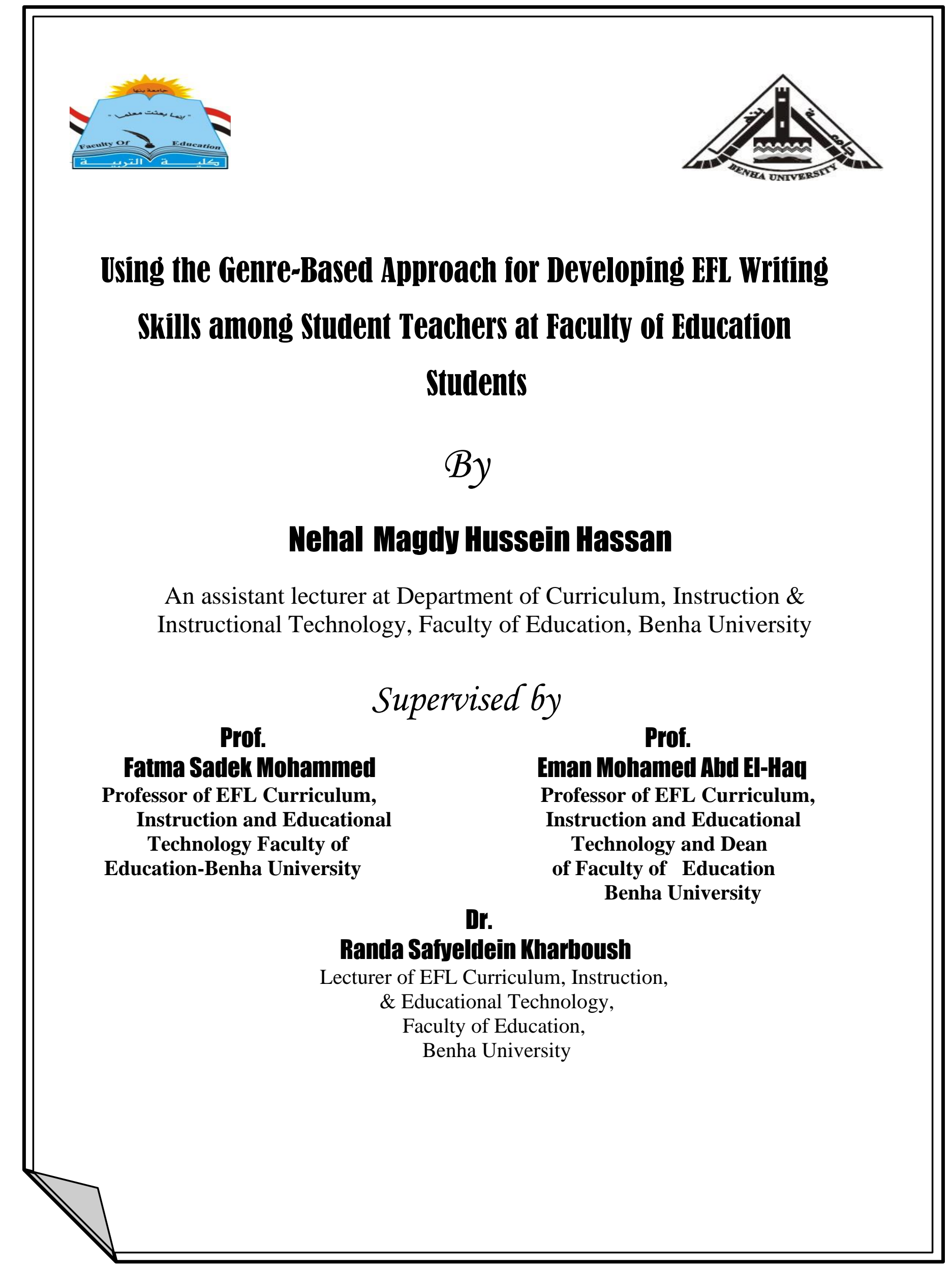




\title{
Using the Genre-Based Approach for Developing EFL Writing Skills among Student Teachers at Faculty of Education Students
}

\begin{abstract}
The aim of the present study was to investigate the effectiveness of using the genre-based approach for developing EFL writing skills among Faculty of Education students. The participants of the study included (50) students (the experimental and control group) enrolled at the English section at Faculty of Education, Benha University. The instruments of the study included EFL writing skills checklist required for third year students, an EFL writing skills test, and an analytic rubric for scoring it. The study followed the two groups (control and experimental) pre-posttest design. After implementing the genre-based approach, the instrument was re-administered to both groups. The results were statistically analyzed and revealed that the experimental groups' EFL writing skills were developed as a result of using the genre-based approach. It is recommended that the genre-based approach can be used in different educational stages for developing EFL writing skills.
\end{abstract}

Keywords: Genre, Genre-based approach, EFL writing skills 


\section{استخدام الملدخل القائم علي تحليل النص لتنمية مهارات الكتابة بالالة

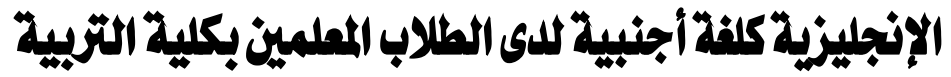

|مستخلص

استهافت الدراسة الحالية الي توضيح اثر استخدام المدخل القائم علي تحليل النص لتتمية مهارات

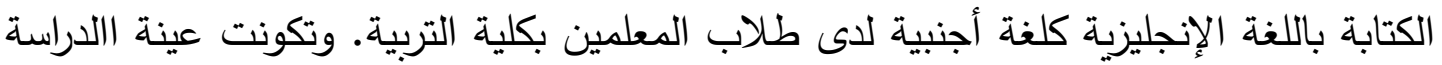

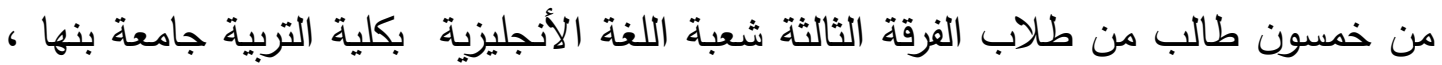
بمحافظة القليوبية. وأشتملت أدوات الدراسة على قائمة بمهارات الكتابة باللغة الإنجليزية اللازمة

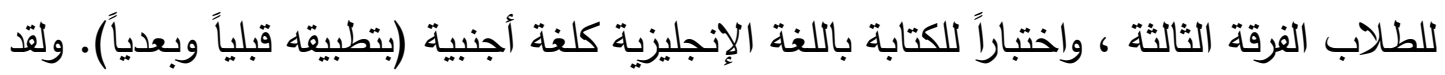



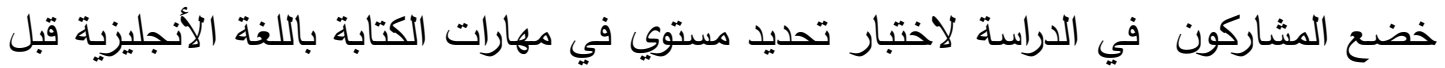
اجراء المعالجة وبعد تطبيق المدخل القائم علي تحليل النص لتحديد فيدائ فاعلية فى تتمية مهارات


الدراسة في مهارات الكتابة باللغة الأنجليزية ، ثم اختبار عينة الدراسة بعد تطبيق المدخل القائم

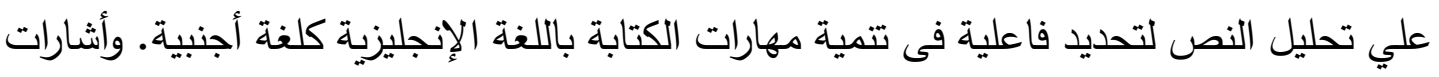

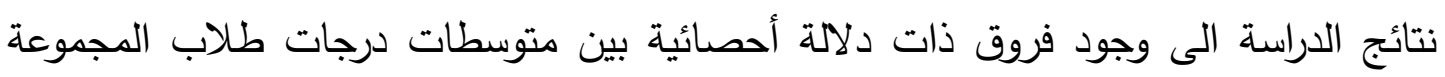

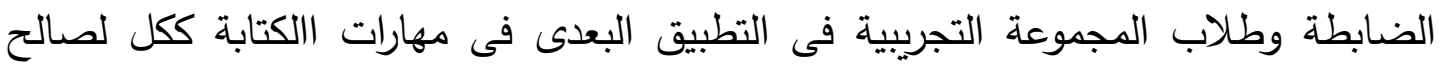



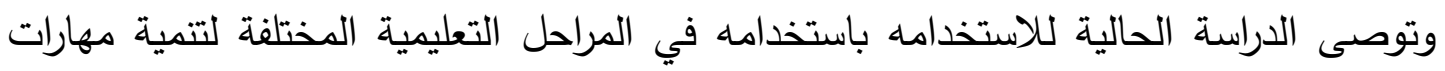
الكتابة اللغة الإنجليزية كلغة أجنبية. الكلمات المفتاحية: تحليل النص - الدذخل القائم علي تحليل النص - مهارات الكتابة باللغة الإنجليزية كلغة أجنبية. 


\section{Introduction}

Language has always been a tool for communicating ideas and thoughts in both spoken and written forms through the history of humankind. Language involves four basic skills (i.e., listening, speaking, reading, and writing). Of the four language skills, writing has always been considered as an important skill contributing to students' language learning. Thus, EFL writing has occupied a strong position as a branch of teaching and learning. Hence, it has been claimed that EFL writing skills are the core of language learning.

Many researchers dealt with EFL writing skills and assigned many definitions, for example, Buainain (2009) defined writing as a psychosocio- mental linguistic skill; writing skills insist on mastering basic processes and sub skills for example, handwriting, punctuation, spelling, word usage, vocabulary, grammar, and the use of strategies; planning, revising and evaluating text. In addition, Brown (2001) described writing kills as a different set of competencies, EFL learners should have, for example, how to generate and organize ideas coherently, how to use discourse markers and rhetorical conventions cohesively into the composition, and how to revise and edit the composition for clearer meaning, as well as how to produce a final product.

Writing is a complex process that involves a series of logical stages (outlining, drafting, revising, editing, and publishing). Although these stages are overlapping in the writing process, they have unique features (Al-Buainain, 2009; Seow, 2002). Concerning the outlining (e.g., prewriting or the planning stage), EFL students outline as a typical activity while writing (Al- Fageeh, 2014). They choose a definite topic, read about the topic, listen to a text related to the selected topic, describe a picture, discuss points for writing or watch a film about the topic and then organize the information into an outline (Mahmoud, 2014; Oshima \& Hogue, 2006). So EFL students struggle more because it requires them to write and generate ideas. These ideas need to be relevant allied (Brown, 2001; Bukhari, 2016). The second one, the drafting stage is the first version of writing. At this stage, EFL students have to focus on central ideas they want to communicate to their different audience (Seow, 2002). They write down these ideas on paper focusing on content not mechanics (Al- 
Buainain, 2009; Mohammad, 2014; Seow, 2002). Therefore, they consider structure of the text, and all the ideas they would include (Al- Fageeh, 2014). There may be a number of drafts before completing the final version. Moreover, drafting is an important and complex set of strategies in which writers need time, patience, and trained instruction to master it.

The third stage is revising in which EFL students focus on the main points, support ideas, organization, and connections between ideas. They proofread their production, look for mistakes concerning language, meaning and form, at the same time, coherence and cohesion (Alodwan \& Ibnian, 2014; Briesmaster \& Etchegaray, 2017; Seow, 2002). Therefore, revising is done to improve the content and organization of ideas in order to make the writer's intent be clear to the reader. The fourth stage is editing in which students' piece of writing would be corrected. This stage may include checking and correcting grammar, punctuation, spelling, cohesive devices, diction, main ideas, sentence connectors, as well as transitions between paragraphs. The final stage of the writing process is publishing, in which the students' writings are revised carefully to be published (Alodwan \& Ibnian, 2014; Kane, 2000; Mohammad, 2014). Therefore, writing is one of the most important skills that EFL students need to achieve while learning to write in English.

In spite of the importance of EFL writing skills, writing in a foreign language is considered one of the challenges for foreign language learners. The level of difficulty increases intensively when conducted in different EFL contexts where the learners are rarely exposed to the demands of writing English. In this sense, the following researchers showed the most common challenges which EFL University students face. For example, Abd-Alfatah (2013) and Al-Bassuony (2017) asserted that EFL students have difficulty planning, composing, revising and evaluating their writings. In addition, they are unable to produce coherent and wellorganized writing texts without errors. This may be due to the emphasis on teaching writing based upon the formal aspects of the written texts with ignoring the functional aspects.

According to Richard and Renandya (2002), the difficulties that EFL students face include generating and organizing ideas using an appropriate choice of vocabulary and putting such ideas into an intelligible 
text. The first difficulty lies in the fact that English in EFL context is treated primarily as a compulsory subject for exam-driven purposes more willingly than as a tool for communication. The second difficulty lies in the fact that most of the teachers just stress providing their student writers with a rich knowledge of vocabulary relating to the specific topic and some guiding questions in order to help them shape their ideas into the completed paragraphs. In this way, teaching writing only helps them produce the error-free texts sticking to the models of correct language. On the other hand, it does not contribute to helping the students realize and master such features as audiences, purpose, context and linguistic conventions of text, which are the important features of any text-types.

Therefore, less attention has been given to text-specific issues and content such as text organization, idea development, coherence and cohesion (Askehave \& Nielsen, 2004; Martínez-Lirola, 2010). Furthermore, EFL students cannot practice writing in various genres since most of their time is spent in practicing isolated skills such as spelling, punctuation, and sentence structure. The main focus is directed to decontextualized drills and activities (Abu Rass, 2015; Al-Bassuony, 2017; Maxwell-Reid, 2014). Therefore, Mansour (2013) asserted that many students still cannot use English effectively for academic or real-life purposes even after completing English courses in secondary school.

These challenges draw the attention to both the significance of writing and call for using effective and different strategies. Therefore, learning to write freely requires a lot of practice in different situations. In this way, EFL writing classes have to pay more attention to engage students in various authentic contexts to improve their writing skills. When considering alternative teaching approaches, it is important to note teachers' perceptions and concepts regarding their teaching practices. Apart from the well-known "product and process" approach of assisting English learners in developing their writing skills, Hasan and Akhand (2010) shed light on a recent methodology, known as genre-based approach, which has been proposed as being applicable to the EFL context. Consequently, this study investigated the feasibility of using the genre-based approach for developing EFL third year students' writing skills. 
In research communities throughout the world, the term "genre" has become a matter of considerable discussion. The term "genre" extracts from the Latin 'genus' which means a category and contains the idea of conventions which construct the different social purposes of text types (Halliday, 2014). Genre refers to the study of how language is used in a certain setting and stresses issues such as rhetorical styles and discourse types (Cope \& Kalantzis, 1993). Also, genre refers to how text is organized and describes the relation between the social purpose of text and language structure (Cusworth \& Ewing, 1994; Nurlaelawati \& Novianti, 2017). In other words, genres are concerned with the relationship between the social contexts in which a text is produced and the linguistic choices made by the writer or speaker (Badger \& White, 2000).

The genre-based approach placed a great emphasis on the relationship between text-genres and their contexts, i.e., it focuses on the social context in which the text is produced and on explanations of the ways in which language utilities in different social contexts (Rusinovci, 2015). Askehave and Nilelsen (2004) defined the genre-based approach as a framework for language instruction depending on examples of a specific genre. The genre framework supports students' writing with systematic guiding principles about how to construct and produce meaningful passages. Eggins (2004) identified a number of characteristics of genre such as a) genre has a specific goal, b) genre has a specific communication event, c) each genre has specific rules including physical form, shape, and content, and d) each genre belongs to a particular discourse community.

Furthermore, the genre based approach gives students a particular purpose for their writing. It provides learners with salient goals which would benefit novice EFL writers. Badger and White (2000) also asserted that the genre approach increases EFL students' awareness of the social context in which the discourse is written. Furthermore. It puts the voice of learners first and the teachers become one of a positive supporter. It also encourages self-expression and risk taking underpinned by an understanding of contextual and social boundaries. It enables the writer to write for pursuing a particular goal. For example, how to retell, how to describe, how to report, how to request, or how something is carried out, 
etc. In this case, the writers need to use linguistic features, a certain social convention, and rhetoric structure of the text. These social purposes of the text-genres help the writers decide the linguistic inputs of the text (i.e., their linguistic conventions, often in the form of linguistic features and schematic structure). Linguistic features consist of linguistic aspects such as vocabulary, grammar, and/or connectors that the writers use for translating information/ideas into a readable text, while schematic structure refers to the internal structure or text organization of the texttype (i.e., introduction, body and conclusion).

It can be concluded that the genre based approach in writing is somewhat new in teaching and learning English. Genre theory is used as a suitable framework for teaching EFL writing and also shows the relationship between the language and its social function (MartínezLirola, 2015; Mosayebnazhad \& Aidinlou, 2015). Genre theory holds that language is functioned in two kinds of contexts (context of culture and situational context). The first is the context of culture (i.e., genre), in which each person shares particular social purposes using the language. This varies according to the second kind of context (situational context), in which language use is related to the basic three features: the topic written about (field), the relationship between the reader and writer (tenor), and the channel of communication either written or spoken (mode). These three features are known as register (Matthiessen \& Halliday 1997).

Genre as an approach provides some stages to go through while writing a particular genre. These stages will guide the writer systematically to be able to produce the composition itself based on the teaching and learning cycle. It comprises four stages: 1) building knowledge of the field; 2) modelling the genre; 3 ) joint construction; and 4) independent construction. In the first step, EFL students brainstorm, question, and discuss. Here, the main aim is to raise awareness of the specific genre and draw EFL students' attention to its features. For the second step, the focus is on text analysis according to the generic (schematic) structure and linguistic features of text. Then the students analyze example texts, considering questions like the following: 1) What is the purpose of the test? 2) How can the writer convince readers that the 
text is important?, and 3) What tenses that the writer uses in the text? Finally, this stage ends with reflection (Reppen, 2002; Susanti, Widiati \& Cahyono, 2020).

The following steps are a joint construction and independent construction in which EFL students work collaboratively to construct a genre and then write the genre alone in the final step (Alidoost, Toulabi, Shahivand, \& Qalavand, 2014). Therefore, in a genre-based writing class, the teacher first builds contextual knowledge of the target genre by concentrating on the purpose of the text, and the context where the writing occurs. After the teacher builds this knowledge, EFL students deconstruct the model text genre, then prepare for independent writing with guidance of the teacher (Alidoost et al., 2014; Badger \& White, 2000; Klimczak, 2011). In this way, the genre-based approach focuses on the social relationship between the writer, audience and context.

Therefore, Harmer (2001) called for a number of factors that EFL students need to consider within reading or writing a particular genre, these are: 1) knowledge of the topic, 2) the audience, 3) the context in which writing will be read, 4) the conventions, and 5) style of the genre. By focusing on the purpose of the text, Klimczak (2011) asserted that learners are producing a text in which the target language culture is embedded, adhering to various genre construction. Also, they can embark on brainstorming the ideas, planning, drafting and editing. Thus, Alidoost et al. (2014) asserted that the genre-based approach deals writing as dominantly linguistic and considers the context, purpose, and writerreader relationship at the same time. Genre-based writing instruction also attempts to provide learners with a wide range of EFL writing skills that will equip them to better tackle authentic writing tasks. Thus, EFL students' writing skills will be improved via realizing the social functions of different genres and the contexts in which they are used.

Consequently, the genre principles used in this study included the notion of scaffolding, the relationship of a text to its context, generic structure, and linguistic features of a text or genre. These aspects of teaching are indirectly embedded in the teaching and learning cycle highlighted in the activities of teaching and learning in the classroom. (Zine, 2014). The notion of scaffolding is based on Vygotsky's theory of 
learning. Such a theory stresses the idea that the teacher provides the students with guidance in order to move through their comfort zone. In this way, the teacher acts as an authoritative role (Mustika, 2016). In this regard, the teacher's role is to support EFL students in learning of target genres and provid the students with a clear understanding of the purpose of text and language use in regard to both a cultural context (genre) and a situational context (field, tenor, and mode). In this case, the students deconstruct models of texts for making sense of the generic structure of the text and linguistic features (Zine, 2014).

There are a number of studies which proved the effectiveness of using the genre-based approach in developing EFL writing skills. Changpueng (2013) investigated the effects of the genre-based approach on EFL students' writing ability. This study was conducted through quasi experimental design. The participations were 52 second year students. The experimental group was taught by using the genre based approach and the control group was taught by using the conventional approach. The instrument was a written test. Before analyzing the data by using t-test, a homogeneity test was conducted, and then scored by using analytical rubric. The results showed that there was a significant effect of genre based approach on EFL students' writing ability. The effects were on the content, organization, language use, vocabulary, and mechanics.

Zine (2014) conducted a study on using the genre-based approach for teaching EFL writing skills. Data has been collected through using two instruments: a structured interview for the teacher and a questionnaire for students. The results confirmed that the genre based approach could be a remedy for both students and teachers in order to overcome the encountered writing difficulties.

Abdel-Malek (2017) investigated the effect of using the genrebased approach in teaching the written recount. The purpose of this study was to (1) conduct a functional grammatical analysis of the recount genre, (2) document the qualitative and quantitative changes in students' writing of a recount genre after the genre-based approach was implemented compared to students' initial writing, (3) examine the relationship between learning to write a recount and reading a recount in the same genre, and (4) observe the meta-language students used during the joint construction 
of a recount with their instructor. Data has been collected through pre/ posttest scores of a written recount, a post-study survey, reading comprehension test scores of a recount, transcription of video-taped genre-based lessons, and an Systemic Functional linguistics analysis of pre/posttest for a focal group of students. Results revealed that there was a significant effect on EFL students' recount genre writing on the posttest compared to the pretest owing to the genre-based approach to writing the recount.

Haerazi, Irawan, Suadiyatno, and Hidayatullah's study (2020) was to develop pre-service teachers' EFL writing skills and creativity through the genre-based instructional model. This study used a quasi-experimental research design. The samples consisted of two classes in which one class was subjected to the process-based instruction (PBI) model and the second class was treated by using the genre-based instructional (GBI) model. The instruments of the study were a creativity test and a writing test. The results revealed that the GBI model was more effective than the PBI model. Therefore, the GBI helped the students have better writing achievement and have high creativity.

To sum up, the genre-based approach guides the students to write from the dependent steps to independent steps. It also promotes the student to learn in an autonomous learning way. Moreover, the genre-based approach is suitable not only for academic setting but also professional setting. In this sense, the genre-based approach will be one of the newest, practical, and effective one to teaching and learning writing.

\section{Context of the problem}

In spite of the importance of EFL writing skills, third year students enrolled in the English section at Benha Faculty of Education lack these skills. Many researchers investigated these weakness among EFL students in all stages and introduced different solutions for this problem such as (Abd-Alaaty, 2013; Akmal, 2017; Al-Fageeh, 2014; El-Banna, 2012; ElSawy, 2015; Mansour, 2015). These studies confirmed that EFL student teachers cannot understand the writing process effectively. Therefore, majority of their writings involve a lot of errors in content (cohesion, coherence, unity, logical order, and so on) and mechanics. This may be 
due to the fact that the main emphasis is placed on grammar and writing mechanics in general. Besides, they lack the ability to develop their ideas smoothly and logically because little emphasis is devoted to teaching writing as a communicative tool. Also, most lecture time was provided to oral skills. On the other hand, other reasons related to EFL students' low awareness about how to produce the different writing genres. This may be due to the fact that little attention is directed to teaching the writing process in terms of genre.

To document the problem of the present study, the researcher conducted a pilot study on a group of 30 second year students enrolled at the English section at Benha Faculty of Education in November, 2018. The pilot study consisted of an EFL writing skills test. The test was adopted from Ali's (2016) study. The results of the pilot study revealed that most of EFL student teachers had poor ability to present logical and well-developed content, lack awareness of organization structures of the writing genres, lack awareness of coherence markers, and make multiple errors in spelling, mechanics, and grammar.

To sum up, teachers can reduce these problems via a friendly atmosphere in the EFL classroom using different effective strategies. They have to give their students opportunities to write without fears and express their ideas in front of their peers. Therefore, the researcher suggested using the genre-based approach for developing their EFL writing skills.

\section{Statement of the problem}

The problem of the present study could be stated as follows:

There is a low level of EFL writing skills among third year students, enrolled at the English section so this may lead them to be poor writers Therefore, the present study is an attempt to investigate the effectiveness of the genre-based approach in developing student teachers' EFL writing skills.

\section{Questions of the study}

To overcome this problem, the present research was an attempt to answer the following questions: 
1. What are the writing skills required for third year students at Faculty of Education?

2. What are the features of the genre-based approach for developing EFL writing skills among student teachers at the Faculty of Education?

3. What is the effect of using the genre-based approach in developing some EFL writing skills among third year students at Faculty of Education?

\section{Delimitations of the study}

The present study was delimited to the following: -

1. A group of third year students enrolled in the English Section at the Faculty of Education, Benha University.

2. Some EFL writing skills that is required for student teachers.

\section{Participants of the study}

The participants of the study were randomly chosen from third year students during the second semester of the 2020-2021 academic year. They comprised 50 students (male/female) enrolled in the English section at Benha Faculty of Education in Qalubia Governorate. The study participants were divided into two groups: - The experimental group $(\mathrm{N}=50)$ who was taught using the genre-based approach and the control group ( $\mathrm{N}=45)$ who was taught using the traditional methods.

\section{Instruments of the study}

To achieve the purpose of the study, the following instrument was developed and used by the researcher: An EFL writing skills test for measuring students' writing skills. It will be used as a pre and posttest and a rubric to score it.

\section{The EFL writing skills test}

The purpose of EFL writing test is to measure EFL student teachers' writing skills before and after implementing the genre-based approach. The test was used as pre/post-test. As pretest, it was used to determine the study participant's level in some EFL writing skills before the treatment. As post-test it was used to investigate the effectiveness of the genre-based 
approach in developing EFL writing skills for third year Faculty of Education students.

\section{Validity of the EFL writing skills test}

To validate the EFL writing test, it was submitted to a panel of EFL jury members $(n=12)$ specialized in curricula and methods of teaching English to identify face validity. They were asked to check the test items and validate it in terms of the suitability for the students 'level and the clarity of test guidelines and instructions. They were also requested to judge whether the test items measure the EFL writing skills that they are supposed to measure. According to the jury members' opinion, they indicated the suitability of the test to its main objectives and the consistency of questions to the test's objectives. Jury members recommended some improvements, which were taken into consideration.

\section{Reliability of the EFL writing skills test}

For estimating the reliability of EFL writing test, the following three methods were used:

\section{(A) Alpha Cronbach method}

It is used to measure reliability coefficient or internal consistency of the test using SPSS, version.18. The reliability coefficient of the test was (.94) according to Cronbach's alpha formula. This showed that the EFL writing skills test is reliable for the purpose it was intended to measure.

\section{(B) Inter-rater reliability}

It refers to the degree to which two or more raters/observers give consistent ratings of the same test after two weeks. Its goal is to achieve objectivity factors in scoring. Accordingly, the test was corrected by two raters. The first rater was the present study researcher. The second one was another researcher* at Benha Faculty of Education. The correlation coefficient between the estimation of the two raters was $(972 * *)$ which is significant at the (0.01) level of significance according to Pearson 
correlation coefficient. This proved a high positive correlation between them.

\section{Aims of the intervention}

The study aimed at developing EFL writing skills for third year students enrolled in the English section, faculty of Education, Benha University. Therefore, by the end of the treatment, the participants would be able to:

1. Make a real use of the language in different social contexts.

2. Convey their ideas using diversity of genres.

3. Express themselves in many different ways.

4. Identify the importance of EFL writing skills to them as prospective teachers in particular.

5. Become learner-centered rather than teacher-centered.

6. Become independent, motivated, confident, and autonomous learners.

7. Evaluate each other in EFL writing skills objectivity.

8. Identify the negative outcomes of EFL writing anxiety and its negative relationship to writing success.

9. Write in non- threatening, encouraging, and motivating atmosphere based on a mutual interaction between the teacher and students.

\section{Duration of the genre-based approach}

The implementation of using the genre-based approach lasted for six weeks with three sessions per week from 8th November to 17th December in the first semester of the academic year 2020-2021. Each session dealt with specific skills and lasted for about two hours except for session one and two that lasted for one hour.

\section{Implementation procedures of the genre-based approach}

\section{Pre-assessment}

Before the implementation of the genre-based approach, the EFL writing skills test was administered to both groups (experimental and control) to make sure that both are equivalent (homogeneous) in the overall EFL writing skills. Instructions for the test were given orally by 
the researcher of the present study. The participants' answers were analyzed and scored. The results revealed that both groups are equivalent (homogeneous).

\section{Implementation of the genre-based approach}

After the study participants were pretested, the experiment was implemented. It lasted for six weeks with three sessions per week 8th November to 17th December in the first semester of the academic year 2020-2021. Each session dealt with a specific skill(s). It covered seventeen sessions. The duration of each session was two hours except for session one and two that lasted for one hour.

In the first session, introductory phase- in which participants were supposed to know definitions of the genre-based approach, its objectives, importance, stages, principle of the approach and some EFL writing subskills-was presented to the study participants, while the rest of the sessions were instructional sessions. At the beginning of each session, the study participants were informed about the objectives of the session, the definition of the skill, the instructional materials, the teacher's role, and the students' role. At the end of each session, the students were given some written activities related to the session in order to make sure that they achieved its objectives. Besides, they were asked to evaluate themselves and other groups using the analytical rubric.

\section{Post-assessment}

At the end of the experiment, the same instrument (the EFL writing skills test) was re-administered to both groups (experimental and control) to investigate the effectiveness of the genre-based approach in developing their EFL writing skills. The results revealed that the genre-based approach is effective in developing EFL student teachers' writing skills.

\section{Assessment techniques used in the genre-based approach}

The assessment system used in this study included both formative and summative assessment.

(A) Formative Assessment: 
Formative evaluation was used for assessing the participants' progress in EFL writing skills and for providing necessary and immediate positive feedback.

\section{(B) Summative Assessment:}

Summative assessment was conducted at the end of the experiment through the application of the EFL writing test to measure the achievement of the intended topics of the approach.

\section{Results and Discussion}

The overall aim of using the genre-based approach was to develop EFL writing skills for third year students, enrolled in the English section at Benha Faculty of Education. To measure the effectiveness of the approach, the two groups were pre-tested on the EFL writing skills. Then the two groups were post-tested using the writing skills test to find whether there was significant difference between the control and the experimental groups in the post assessment of the test. To test this hypothesis, independent-samples t-test was used. The following table presents the mean scores, standard deviations (S.D), t-value and level of significance of the control group and that of the experimental group in the postassessment of the overall EFL writing skills test.

Table (1): Results of the $t$ - test between the mean scores of the experimental group and the mean scores of the control group in the post-assessment of the overall EFL writing skills

\begin{tabular}{lcccccc}
\hline & Group & N. & Mean & S.D. & t-value & D.F. \\
Overall & Sig. & & & & & \\
\cline { 2 - 7 } EFL writing skills & Cont. & 45 & 63.5333 & 4.65930 & \\
& & & & 12.282 & 93 \\
& $\begin{array}{c}0.01 \\
\text { Exp. }\end{array}$ & 50 & 82.0200 & 9.07450 & \\
\hline
\end{tabular}

The above table indicated that the mean scores of the control group in the post-assessment of the overall writing skills test (63.5333) are lower than the mean scores of the experimental group of the same test (82.0200), 
where -value is (12.282) which is significant at the 0.01 level of significance. This change in the experimental group students' level of the overall EFL writing skills may be due to the genre-based approach which the participants of the present study participated in. Therefore, this hypothesis was verified.

Based on the aforementioned results, it can be said that the participants' EFL writing skills were developed after the implementation of the treatment. There were noticeable developments in the EFL writing skills among student teachers. These differences in the level of the experimental group students may be due to the effective of the genrebased approach which contained various activities, including brainstorming, discussion, self-assessment checklist, group work activities and pair work activities. These activities helped the participants write their essays depending on real texts written by native speakers and also enabled them to engage in non-threatening atmosphere.

Furthermore, These EFL writing activities were interesting and suitable for both the students' level and the time allocated for each session. These activities also ranged from simple to more challenging ones for giving the students the chance to experience success. Besides, these activities motivated the students to think, express their feelings and thoughts and overcome their fears that hinder them from writing freely. Accordingly, the activities related to formative assessment helped them greatly in correcting their errors. In this sense, their errors also decreased because of the continuous feedback the approach presented resulting in an increase in EFL writing skills.

The current results were consistent with the results of previous studies which proved the great contribution of the genre- based approach in developing EFL writing skills such as (Abdel-Malek, 2017; Changpueng, 2013; Khanyile, 2015; Mustika, 2016; Nurazidha, 2017). These results indicated that the students became more independent writers and their confidence in writing increased. In addition, the genre-based approach not only helped the students solve immediate EFL writing problems, but also promoted their awareness of different kinds of writing (text types): argumentative, persuasive, discursive, narrative, critical, 
expository (explanatory), and descriptive writing or texts. Consequently, the participants reported that they have benefited from the genre-based approach and noticed their improvement in EFL writing skills. Thus, they want such a treatment to develop other English language skills.

Consequently, it could be included that using the genre-based approach was effective in developing EFL third year students' writing skills.

\section{Recommendations of the study}

In the light of the study results, the following recommendations can be presented:

1. EFL teachers should provide more chances for their students to use the target language in an authentic environment.

2. EFL teachers should stress peer and group work activities that let students communicative and interact with each other.

3. Teacher educators should promote the scaffolding concept that presents information in small chunks so teaching should be turned from being teacher-centered to learner-oriented in which learners become more involved in and responsible for their learning and become self-autonomous.

4. EFL teachers' roles in using the genre-based approach should range from a motivator, a facilitator, a modernizer to an organizer.

5. Teachers should pay attention to their students' learning needs and individual differences in the EFL classroom.

6. Students should be engaged in social and authentic context to gain satisfaction, self-confidence and reduce students' speaking anxiety.

\section{Suggestions for further research}

Based on the results of the present study, the following suggestions for further research were presented:

1. Investigating the effectiveness of the genre- based approach in developing EFL other language skills among Faculty of Education students. 
2. Investigating the effectiveness of the genre- based approach on special needs students.

3. The effectiveness of genre analysis and genre-based approaches in developing EFL academic writing skills.

4. The effectiveness of the genre-based approach in developing students' attitudes towards EFL creative writing skills.

5. The effects of critical genre-based approach on developing EFL critical writing skills.

\section{References}

Abd-Alfatah, N. A. (2013). The effect of a program based on brainstorming strategy in developing writing paragraph for preparatory stage students. Studies in Curricula and Teaching Methods, (193), 58-67. Retrieved from https://search.mandumah.com.

Abd-Alaaty, Y. S. M. (2013). The effectiveness of using weblog in developing the writing skills of EFL prospective teachers. Journal of Reading and Knowledge, 145, 1-23. Retrieved from https://search.mandumah.com.

Abd-alrahim, A. M., \& Abu-shawish, G. I. (2012). Writing apprehension among Palestinian university English majors: Causes and solutions. Al - Aqsa University Journal (Human Sciences Series), 16(2), 114150.

Abdel-Malek, M. (2017). A genre-based approach to teaching the written recount in Arabic: A mixed methods investigation (Unpublished 
doctoral dissertation). The Graduate Faculty of the School of Education, University of Pittsburgh: Pittsburgh.

Abu Rass, R. (2015). Challenges face Arab students in writing well developed paragraphs in English. English Language Teaching, 8(10), 19-60. Retrieved from https://dx.doi.org.

Akmal, T. (2017). Impact of web based learning on EFL: Using on-line discussion forum (ODF) to enhance students' writing skill. Universal Journal of Educational Research, 5(8), 1345-1348. Retrieved from https://www.hrpub.org.

Al-Buainain, H. A. (2009). Students' writing errors in EFL: A case study. Alexandria Faculty of Education Journal, 19 (1), 310-351. Retrieved from http://search.mandumah.com.

El-Bassuony, J. M. (2017). The role of the multisensory approach in developing English writing skills and metacognitive awareness of struggling writers at the preparatory stage. Studies in Curricula and Teaching Methods, (226), 41-95. Retrieved from https://search.mandumah.com.

Al-Fageeh, A. A. (2014). Effects of using wikis for developing Saudi EFL students 'reading and writing skills. Umm Al - Qura University Journal of Languages and Literature, 14, 7-37. Retrieved from: https://www.sciencedirect.com.

Alidoost, Y., Toulabi, A. R., Shahivand, Z., \& Qalavand, M. (2014). A genre-based teaching approach to academic writing: Describing visually presented information in graphs and charts. International Journal of Language Learning and Applied Linguistics World (IJLLALW) (Online). 5 (2), 78-83. Available from https://www.ijllalw.org.

Alodwan, T. A., \& Ibnian, S. S. K. (2014). The Effect of using the process approach to writing on developing university students' essay writing skills in EFL. American Research Institute for Policy Development (Online), 3(2), 139-155. 
Askehave, I., \& Nilelsen, A. E. (2004). Web-mediated genres: A challenge to traditional genre theory. Denmark: Centre for Virsomhedskommunikation. Retrieved from https:///www.asb.dk.

Badger, R., \& White, G. (2000). A process genre approach to teaching writing. ELT Journal Volume, 54(2), 153-160. Retrieved from https://www.researchgate.net/publication/31211657.

Briesmaster, M. \& Etchegaray, P. (2017). Coherence and cohesion in EFL students' writing production: The impact of a metacognition-based intervention. Ikala, Revista de Lenguaje y Cultura 22(2), 183-202. Retrieved from http://www.udea.edu.com.DOI: 10.17533/udea.ikala.v22n02a02.

Brown, H. D. (2001). Teaching Principles: An Interactive Approach to Language Pedagogy (2nd Ed.). San Francisco: San Francisco State University.

Bukhari, S. S. F. (2016). Mind mapping techniques to enhance EFL writing skill. International Journal of Linguistics and Communication (Online), 4 (1), 58-77. Retrieved from: https://doi.org/10.15640/ijlc.v4n1a7. DOI: 10.15640/ijlc.v4n1a7.

Changpueng, P. (2013). The effects of the genre-based approach on EFL students' writing ability. Social Sciences \& Humanities, 21 (2), 735 756.

Cope, B., \& Kalantzis, M. (1993). The powers of literacy: A genre approach to teaching writing. London: Routledge.

El-Banna, A. I. (2012). The effect of computer-assisted language learning morphology on developing EFL prospective teachers' writing skills. Studies in Curriculum and Instruction, (189), 74-40. Retrieved from https://search.mandumah.com.

El-Sawy, H. E. A. (2015). The impact of Facebook as a free writing tool on developing EFL writing skills. Benha Faculty of Education Journal, 26 (104), 1-28. Retrieved from https://search.mandumah.com. 
Halliday, M. A. K. (2014). Halliday's introduction to functional grammar ( $4^{\text {th }}$ Ed.). USA: Routledge. Retrieved from https://www.books.google.com.

Haerazi, H., Irawan, L. A., Suadiyatno, T., \& Hidayatullah, H. (2020). Triggering pre-service teachers' writing skills through genre-based instructional model viewed from creativity. International Journal of Evaluation and Research in Education (IJERE), 9(1), 234-244. Retrieved from homepage: http://ijere.iaescore.com.

Hasan, K., \& Akhand, M. M. (2010). Approaches to writing in EFL/ESL context: Balancing product and process in writing class at tertiary level. Journal of NELTA, 15(1), 77-88. Retrieved from https://doi.org/10.3126/nelta.v15i1-2.4612.

Kane, T. S. (2000). The oxford essential guide to writing. New York: Berkley.

Khanyile, B. M. (2015). A genre-based approach to teaching writing across the curriculum in SiSwati in South African schools (Unpublished master thesis). Faculty of African Languages, Stellenbosch University.

Klimczak, A. (2011). Genre approach to teaching formal letter writing. In J. Majer \& L. Salski (Eds.), Foreign language opportunities in writing (FLOW) (pp.202-213). LODZ University Press: Poland.

Mahmoud, M. M. A. (2014).The effectiveness of using the cooperative language learning approach to enhance EFL writing skills among Saudi university students. Journal of Language Teaching and Research, 5(3), 616-625. doi:10.4304/jltr.5.3.616-625.

Mansour, G. A. I. (2013). A suggested program for developing EFL reading and writing skills among secondary school students in light of the constructivist learning approach. Studies in Curricula and Teaching Methods, (194), 1-27. Retrieved from https://search.mandumah.com.

Mansour, H. A. A. (2015). A program based on self-regulated strategy development approach for developing the teaching and writing 
performance of EFL student teachers. Journal of Scientific Research in Education, 4(16), 665-685. Retrieved from https://search.mandumah.com.

Martínez-Lirola, M. (2015). The use of genre theory for improving writing proficiency skills in explanations. Revista de Lenguaje y Cultura, 20(2), 189-204. Retrieved from: https://www.udea.edu.co/ikala.

Martínez-Lirola, M. (2010). How to apply SFL in classroom practice: An example in bilingual education programs in the USA. The Buckingham Journal of Language and Linguistics, 3, 205-219.

Matthiessen, C., \& Halliday, M. A. K. (1997). Systemic functional grammar: A first step into the theory. China: Higher Education Publishing House.

Maxwell-Reid C. (2014). Genre in the teaching of English in Hong Kong: A perspective from systemic functional linguistics. In D. Coniam (Ed.), English Language Education and Assessment: Recent developments in Hong Kong and the Chinese mainland (pp. 87-102). Singapore: Springer.

Mohammad, H. A. (2014). The effect of strategy-based writing instruction on EFL learners' writing skills. Menofia Faculty of Education Journal, 29 (3), 1-40. Retrieved from https://search.mandumah.com.

Mosayebnazhad, F., \& Aidinlou, N. A. (2015). The effect of the systemic genre instruction on the writing performance of Iranian EFL high school students. MAGNT Research Report, 3(1), 377-388.

Mustika, M. (2016).The implementation of genre-based approach to improve the writing skill of the seventh grade students of SMP institute Indonesia (Unpublished master thesis). Faculty of Languages and Arts, Yogyakarta state university: Nigeria.

Nurazidha, H. F. (2017). The implementation of genre-based approach in teaching reading skill at the tenth grade students of man Karanganyar in the academic year 2016/2017 (Unpublished master thesis). Islamic Education and Teacher Training Faculty, Surakarta. 
Nurlaelawati, I., \& Novianti, N. (2017). The practice of genre-based pedagogy in Indonesian schools: a case of pre-service teachers in Bandung, west java province. Indonesian Journal of Applied Linguistics, 7(1), 160-166.

Oshima, A., \& Hogue, A. (2006). Writing Academic English. New York: Longman.

Reppen, R. (2002). A genre-based approach to content writing instruction. In J. C.

Richards \& W. A. Renandya (Eds.), Methodology in language teaching: An anthology of current practice (204-211). New York: Cambridge University Press.

Richards, J. C., \& Renandya, W. A. (Eds.). (2002). Methodology in language teaching: An anthology of current practice. New York: Cambridge University Press. Available from https://www.cambridge.org.

Rusinovci, X. (2015). Teaching writing through process-genre based approach. US-China Education Review, 5(10), 699-705.

Seow, A. (2002). The writing process and process writing. In J. C. Richards \& W. A. Renandya (Eds.), Methodology in language teaching: An anthology of current practice (204-211). New York: Cambridge University Press.

Susanti, A., Widiati, U., \&, Cahyono, B. Y. (2020). The effect of proficiency pairings on EFL students' writing ability in genre-based approach context. International Journal of Evaluation and Research in Education (IJERE), 9(1), 245 251. Retrieved from http://ijere.iaescore.com.

Zine, A. (2014). The genre-based approach to teaching writing for business purposes (Unpublished doctoral dissertation). University Mohamed Boudiaf, M'sila, Algeria. 